\title{
Serodetection Bovine Herpesvirus Types 1, 4 and Bovine Parainfluenza Virus Type 3 Infections in Milk of Cows with Clinical Mastitis Based in Dairy Cattle Management in Turkey
}

\author{
Bayram Celik ${ }^{1}$ and Mehmet Kale ${ }^{1^{*}}$ \\ ${ }^{1}$ Department of Virology, Faculty of Veterinary Medicine, University of Burdur Mehmet Akif Ersoy, \\ 15030, Burdur, Turkey.
}

Authors' contributions

This work was carried out in collaboration between both authors. Both authors read and approved the final manuscript.

Article Information

DOI: $10.9734 / A R R B / 2020 / v 35 i 130178$

Editor(s):

(1) Dr. Xiao-Xin Yan, Professor, Department of Anatomy and Neurobiology, Central South University Xiangya School of Medicine (CSU-XYSM), China. Reviewers:

(1) Sandra E. Perez, National University of Central Buenos Aires, Argentina (2) Ekram Wassim, Alexandria University, Egypt. Complete Peer review History: http://www.sdiarticle4.com/review-history/53859

Original Research Article

Received 10 November 2019

Accepted 15 January 2020

Published 14 March 2020

ABSTRACT

Aims: The present study aimed to Searching Bovine Herpesvirus Types 1, 4 and Bovine Parainfluenza Virus Type 3 Infections in Milk of Cows with Clinical Mastitis Based in Dairy Cattle Managements.

Study Design: In 35 managements around Burdur region, milk of 123 cows with clinical mastitis was searched for Bovine Herpesvirus Types 1 (BHV-1), 4 (BHV-4) and Bovine Parainfluenza Virus Type 3 (BPIV-3) infections.

Results: In the study, the highest seropositivity was detected against BPIV-3. The highest seropositivity on infection distribution according to age was found against every four viruses in animals within the three-year-old group. The highest seropositivity in this group and other age groups was detected against BPIV-3. Seropositivity against these viruses was found in the highest right anterior one and the lowest left posterior one out of determined udder lobes. The highest seropositivity was found in semi-outdoor managements with concrete and dirty grounds where cleaning/disinfection of teats before and after milking was performed, mastitis treatment and viral 
vaccination was not applied, the ground of stable was cleaned monthly, only feces was collected from the grounds, water was used for cleaning of milking machines and hands and iodised disinfectant was used. During udder inspection evaluation of animals with clinical mastitis, the highest seropositivity was detected in the ones having normal udder, teat and skin appearance. Out of udder and teat skin lesions, the highest seropositivity was found in crushed ones. In the evaluation of udder palpation in animals with clinical mastitis, the highest seropositivity was detected in the ones with teat tissue thickening and with elastic teat sinuses and lobes. In the milk of these animals, the highest seropositivity was found in the ones showing coagulation.

Conclusion: It was stated that viruses took a vital part in clinical mastitis cases, the structure, practice, cleaning and disinfection of managements was really important, udder and teat skin lesions, tissue thickening, elastic teat sinuses and lobes and coagulation of milk was also crucial. Besides, the appearance of udder, teat and skin was not relevant.

Keywords: Cow; clinical mastitis; milk; viruses.

\section{INTRODUCTION}

Mastitis is defined as the inflammation developing in parenchyma tissue of one or more udder lobes resulting from toxic, traumatic or infectious factors. Mastitis is characterized by pathological disorders in mammary gland and physical, chemical and frequent bacteriological changes in milk [1].

In many studies to detect aetiology in mastitis cases, no etiological agent could be detected in $20-35 \%$ of the cases [2,3]. In this case, researchers claimed that there could be factors in small quantities or hardly isolated agents such as fungi, yeast or chlamydia except bacteria could be possible. Watts [3], who detected 137 microorganisms causing mastitis, did not include viral etiology in his study. The virus infections within bovine clinical and subclinical mastitis were reported as Bovine herpesvirus type 1 and type 4 (BHV-1 and BHV-4), Bovine Parainfluenza type 3 virus (BPIV-3), Foot and mouth disease virus (FMDV) and Bovine leukemia virus (BLV) $[4,5,6,7,8]$. Besides, Bovine herpesvirus type 2 (BHV-2), Bovine vaccinia virus (BVV), Cowpox virus, Pseudocowpox virus, Bovine vesicular stomatitis virus (BVSV), Bovine papillomavirus (BPV), Bovine viral diarrhoea virus (BVDV), Bovine immunodeficiency virus (BIV) and Rinderpest virus (RPV) were stated to have caused bovine mastitis indirectly $[9,10,11,12$, $13,14,15,16]$.

\section{MATERIALS AND METHODS}

\subsection{Animals and Properties Managements}

of

In this study, milk samples were collected from four udder lobes of each of 123 Holstein dairy cattle over three years old with clinical mastitis. Animals with blind teats were not included in the study. Samples were collected from animals whose BHV-1 and BPIV-3 vaccinations were not applied. Because constant vaccination procedure (2-3 times a year) against FMDV disease is applied for all dairy cattle for protection in our country, this was not included in our search study in terms of the viral agent (since vaccination based positivity would be detected). For prediagnosis of clinical mastitis, methods of udder inspection and palpation and evaluation of milk appearance (physical examination) were used. In the study, systemic symptoms that might be seen in cows with mastitis (fever, increase in pulse and respiration, inflammatory symptoms in mammary gland, weakness, lack of appetite, pause in rumen movements etc.) were not taken into consideration. A total of 35 managements were searched. Questions and replies about the properties of animals and management were recorded.

\subsection{Udder Inspection}

Sizes of udder parts and teats (in proportion to one another), shape of udder (droopy, skewed), appearance of teat and skin (strained, crumpled, colour changes), udder and teat skin lesions (ragged, crushed, cut wounds, crustation, necrosis, fistule, ulcer, oedema) were evaluated.

\subsection{Udder Palpation}

Evaluations of teat tissue thickening in terms of fibrosis aspect, controlling of udder sinuses (condition of softness and elasticity) and palpation of udder lobes (modal form, condition of softness and elasticity) were performed.

\subsection{Evaluation of the Appearance of Milk}

Colour change, dilution, smell, flacon or coagulation was searched in collected milk. A 
black, flat ground was used in these examinations.

\subsection{Milk Samplings}

Milk samples were taken into $10 \mathrm{~mL}$ sterile glass tubes(Vacutest. Arzergrande, Italy) from each udder lobe of animals having clinical mastitis. Collected milk samples were transferred into laboratory environment in the cold chain.

\subsection{Collecting Milk Serum}

After adding $0.2 \mathrm{~mL}$ rennin (Merck, Darmstadt, Germany) and $0.1 \mathrm{~mL}$ saturated $\mathrm{CaCl}_{2}$ (Merck, Darmstadt, Germany) onto milk samples were taken as $10 \mathrm{~mL}$ into sterile glass tubes (Vacutest. Arzergrande, Italy), they were incubated for $1 \mathrm{~h}$ at $37^{\circ} \mathrm{C}$. Later they were centrifuged for $20 \mathrm{~min}$ at $720 \mathrm{~g}$ and the cream layer was removed by the help of a spatula. Milk serum was collected using a pasteur pipette and was inactivated in a water bath for $30 \mathrm{~min}$ at $56^{\circ} \mathrm{C}$ before taken into deep freezer. Milk serum was kept in a $-40^{\circ} \mathrm{C}$ deep freezer until applying ELISA test.

\subsection{BHV-1, BHV-4 and BPIV-3 ELISA (Milk)}

In the milk serum samples taken from animals in managements, ELISA BHV-1 (BioX Diagnostics, $\mathrm{BHV}-1$ BIO K 238, Belgium) seroconversion detection commercial testing product was used to detect antibody presence against BHV-1, ELISA BHV-4 (BioX Diagnostics, BHV-4 BIO K 312, Belgium) antibody detection against BHV-4 and ELISA BPIV-3 (BioX Diagnostics, BPIV-3 BIO K 239, Belgium) seroconversion detection against BPIV-3. The tests were performed according to kit procedures. All the plates were read under ELISA reader (Mindray, MR-96, Germany). The obtained positive, negative and optical density results of samples were evaluated according to kit procedure. Validation of all tests was confirmed before the evaluation.

\section{RESULTS}

\subsection{Animals and Properties Management}

Surveys with breeders were applied in managements where seropositivity was detected. Animals and management where no vaccination was performed against BHV-1 and BPIV-3 were studied. Out of samples taken separately from four teat lobes of each animal, seropositivity against viruses was detected only in the four teat lobes of one animal. Within 35 managements, average seropositivity rate was found as $35.4 \%$ for right front teats, $30.2 \%$ for right rear teats, $21.8 \%$ for left front teats and $12.6 \%$ for left rear teats, average seropositivity distribution according to stable properties were found as $30.8 \%$ for indoor ones, $21.3 \%$ for outdoor ones and $47.9 \%$ for semi-outdoor ones. Average seropositivity distribution according to stable location was detected as $65.3 \%$ for concrete ones, $10.2 \%$ for inlay ones and $24.5 \%$ for soil ones, average seropositivity distribution according to cleanness of stable ground was found as $82.4 \%$ for dirty ones and $17.6 \%$ for clean ones, and because milking was performed by machines in all managements, average seropositivity distribution was detected as $100 \%$. Average seropositivity distribution was found as $71.4 \%$ in managements where teat cleaning/disinfection was applied before and after milking and $28.6 \%$ where it was not applied, $42.8 \%$ where mastitis treatment was applied previously and $57.2 \%$ were not applied, $12.4 \%$ where stable ground cleaning was performed daily, $28.3 \%$ where performed weekly and $59.3 \%$ were performed monthly, $29 \%$ where stable ground was cleaned with water, $8.7 \%$ with disinfectants and $62.3 \%$ only by collecting feces, $80.9 \%$ where milking machines were cleaned with water, $16.4 \%$ with disinfectants and $2.7 \%$ with no cleaning, $92 \%$ where hands were cleaned with water, $1.4 \%$ with disinfectants and $6.6 \%$ with no cleaning, and $97.8 \%$ where iodised disinfectant was used and $2.2 \%$ were not used. The distribution of sampled animals according to ages is shown in Table 1. The distribution of infection according to ages is shown in Table 2.

\subsection{Udder Inspection}

Average seropositivity distribution was detected as $62.5 \%$ for animals with normal udder shape,

Table 1. The distribution of sampled animals according to ages

\begin{tabular}{ll}
\hline Ages (year) & Numbers of animal (n, \%) \\
\hline 3 & $56(45.5 \%)$ \\
4 & $27(22 \%)$ \\
5 & $17(13.8 \%)$ \\
6 & $11(8.9 \%)$ \\
7 & $6(4.9 \%)$ \\
8 & $5(4.1 \%)$ \\
9 & $1(0.8 \%)$ \\
\hline Total & $123(100 \%)$ \\
\hline
\end{tabular}


Table 2. The distribution of infection according to ages

\begin{tabular}{llll}
\hline Ages (year) & BHV-1 (n, \%) & BHV-4 (n, \%) & BPIV-3 (n, \%) \\
\hline 3 & $44(35.8 \%)$ & $37(30.1 \%)$ & $56(45.5 \%)$ \\
4 & $15(12.2 \%)$ & $15(12.2 \%)$ & $27(22 \%)$ \\
5 & $10(8.1 \%)$ & $8(6.5 \%)$ & $17(13.8 \%)$ \\
6 & $5(4.1 \%)$ & $5(4.1 \%)$ & $11(8.9 \%)$ \\
7 & $2(1.6 \%)$ & $1(0.8 \%)$ & $6(4.9 \%)$ \\
8 & $2(1.6 \%)$ & $1(0.8 \%)$ & $5(4.1 \%)$ \\
9 & $1(0.8 \%)$ & $1(0.8 \%)$ & $1(0.8 \%)$ \\
\hline Total & $79(64.2 \%)$ & $68(55.3 \%)$ & $123(100 \%)$ \\
\hline
\end{tabular}

Table 3. Distribution of seropositivity in single, double and triple infection results

\begin{tabular}{ll}
\hline Viruses & Seroposivity rates $(\mathbf{n}, \%)$ \\
\hline BHV-1 & $79(64.2 \%)$ \\
BHV-4 & $68(55.3 \%)$ \\
BPIV-3 & $123(100 \%)$ \\
BHV-1 + BPIV-3 & $15(12.2 \%)$ \\
BHV-4 + BPIV-3 & $9(7.3 \%)$ \\
BHV-1 + BHV-4 + BPIV-3 & $39(31.7 \%)$ \\
\hline
\end{tabular}

$25 \%$ for droopy ones and $12.5 \%$ for skewed ones, $60 \%$ for animals having the normal appearance of teat and skin, $10 \%$ for tight ones and $30 \%$ for crumpled ones. However, no colour change was observed. Average seropositivity distribution on udder and teat lesions was found as $27.9 \%$ for crushed ones, $15.8 \%$ for ragged ones, $6.3 \%$ for cut wounds, $18.5 \%$ for oedema, $7.7 \%$ for crustations and $2.5 \%$ for fistules. No skin lesions were observed for $21.3 \%$.

\subsection{Udder Palpation}

Average seropositivity distribution was found as $7.7 \%$ for tissue thickening in teats while it was $92.3 \%$ in teats with no thickening. Fibrosis formations were not observed in teats. Seropositivity was found as $26.2 \%$ for animals with soft udder sinuses and lobes and $73.8 \%$ with elastic ones.

\subsection{Evaluation of the Appearance of Milk}

In terms of the appearance of milk, average seropositivity distribution was detected as $10.4 \%$ for diluted ones, $78.4 \%$ for coagulated ones and $11.2 \%$ for the ones with colour change. Distribution of seropositivity in single, double and triple infection was shown in Table 3.

\section{DISCUSSION}

Cow milk constitutes $83 \%$ of total world milk production. $54 \%$ of world cow and buffalo dairies are located in Asia and Europe continents. Based on countries, some particular regions have a critical importance in terms of milk production. According to data in 2014, Turkey is one of the rare countries with an annual growth rate of more than $3 \%$ in terms of relevant milk production. Turkey was reported to have produced 16 million tonnes of milk in 2014 [17].

Microorganism groups are the primary reason of cattle mastitis. Microorganisms causing cattle mastitis are Staphylococcus, Streptococcus, gram-negative bacteria, mycoplasma, chlamydia, Arcanobacterium pyogenes, fungi, mould, ferments and viruses [18]. Not many studies were performed especially on viruses.

In this study, BHV-1, BHV-4 and BPIV-3 infections were studied in the milk of 123 cows with clinical mastitis in 35 managements around Burdur region. Seropositivity against BHV-1 was detected in $64.2 \%(79 / 123)$ of milk samples. Karaduman and Gur [4] studied the role of BHV1 infection in subclinical and clinical mastitis cases in dairy managements. In their study, they diagnosed 15 cows with clinical mastitis and detected BHV-1 seropositivity in $8(53.3 \%)$ of them. They also found the infection rate as $40.9 \%$ for cows with subclinical mastitis. Siegler et al. [19] reported that mastitis incidence was higher than normal in herds where BHV-1 and BVDV infections were seen together. Besides, in herds taken under control in terms of BHV-1 and BVDV, mastitis rates were found low despite the existence of mastitis caused by Staphylococcus 
and Streptococcus. Some researchers $[20,21,22]$ reported that the virus replicated in mammary gland when BHV-1 was inoculated inside teats and that clinical mastitis developed. In teat lobes where the virus was inoculated, swelling, sensitivity and stiffening were found as symptoms, milk composition collapsed and milk yield decreased considerably. Unlike these situations, Herlekar et al. [23] studied BHV-1, BHV-2, BHV-4 and BVDV presence in milk samples by real-time PCR. They found BHV-1 seropositivity in $10 \%$ of milk samples they collected from cows. Bilge [24] performed BHV-1 isolation in only one milk sample out of 96 cows with mastitis. Wellenberg et al. [6] could not detect BHV-1 from 58 clinical mastitis cases naturally occuring in ten herds.

In the study, BHV-4 seropositive animals were determined at a level of $\% 55.3(68 / 123)$. Ali et al. [25] studied BHV-4 presence in the milk of cows with clinical or subclinical mastitis. In their study, they searched for BHV-4 presence in 176 milk samples using ELISA (antibody), PCR and virus isolation tests. In the study, they found antibody presence in 173 of the samples (98.2\%) and viral genome presence in $2(1.3 \%)$. However, no virus isolation was performed in two samples where BHV-4 viral genome was detected. Wellenberg et al. [6] performed the first isolation of BHV-4 on the milk samples of cows with clinical mastitis. They isolated BHV-4 on the milk of three cows in three different herds. They also reported that antibody against BHV-4 developed in $16 \%$ of cows with mastitis and $10 \%$ of control groups. Herlekar et al. [23] studied BHV-1, BHV-2, BHV4 and BVDV presence in milk samples by realtime PCR. They found BHV-4 seropositivity in 0.7 $\%$ of milk samples they collected from cows.

In the study, the highest seropositivity was detected against BPIV-3. This rate was found as $100 \%$ (123/123). Kawakami et al. [26] detected respiratory problems, fever, weight loss, lumps and stiffness in tit lobes, change in milk color and increases in milk $\mathrm{pH}$, mammary gland epithel cells, neutrophils, lymphocytes and monocytes in cattle as a result of in-mammary inoculations they performed experimentally with BPIV-3. After the $10^{\text {th }}$ day of inoculation to all tits, they found high titer $\left(>10^{7} \mathrm{DKID}_{50} / 0.1 \mathrm{ml}\right)$ virus presence in milk. They observed interstitial inflammation and dense lymphoid cells in their histological studies. Kawakami et al. [26] stated that teat tissues were sensitive to BPIV-3 virus and mastitis might develop in naturally infected cows with this virus. Woods et al. [7] searched viral agents in mammary lymph nodes of 42 Hereford cows with low reproductive performance. They detected BPIV-3 virus seropositivity in all blood serum samples of these animals. Valarcher and Hagglund [27] found the BPIV-3 seropositivity rate as $100 \%$ in blood samples of cattle in Southern and Central France.

Although antibodies against BHV-1, BHV-4 and BPIV-3 were detected in milk samples of animals with clinical mastitis in this study, antibodies that appeared due to systemic infections because of inflammation within the udder in mastitis might also be transmitted to milk. Therefore, we believe that these antibodies obtained from milk might be related not only with udder infection but also with systemic infection.

BPIV-3 seropositivity was mostly seen in double and triple mixed virus infections. BPIV- 3 is common among adult cattle all around the world and has the highest seroprevalence [28]. It was stated that BPIV-3 was quite sensitive to mammary glands, teats could be infected in natural BPIV-3 virus infections and end up with clinical mastitis cases [29]. In this study, the highest seropositivity in infection distribution according to age was found against every three viruses in animals of three-year-old age groups. In this group and other age groups, the highest seropositivity was detected against BPIV-3. Age is a crucial preparatory factor in mastitis. In some studies, the risk of mastitis is said to have increased with age increase [30]. This condition, depending on age increase, is associated with the increase in teat gap, decrease in local defence mechanisms, continuous birth and the increase in environmental bacterial contamination in birth [31,32]. Besides, cows were under stress and their immune systems are weaker in multi-births. Generally, immunity might be weak and lead to mastitis in old animals [31]. In our study, no comments were available since the number of animals in each age group were different.

Out of detected udder lobes, seropositivity against at least one of each three viruses was found in the highest right front and the lowest left behind ones. The highest seropositivity was detected in semi-outdoor, concrete ground and dirty ground managements where teat cleaning/disinfection was applied before and after milking, mastitis treatment and viral vaccination was not applied, stable ground cleaning was performed monthly, only faeces was collected from the ground, milking machines and hands were cleaned with water and iodised disinfectant was used. In managements with high 
mastitis prevalence, low hygiene conditions and low milking hygiene applications existed [33]. As a result, during milking, pathogens might spread around [34]. Çetin and Alan [35] encountered mastitis cases in 125 right front, 113 right rear, 116 left fronts and 125 left rear udder lobes of cows. Ali et al. [36] found clinical mastitis cases in right front mammary lobes of buffaloes at a rate of $19.29 \%, 26.32 \%$ in right rear mammary lobes, $12.28 \%$ in left front mammary lobes and $34.21 \%$ in left rear mammary lobes.

As Biffa et al. [30] studied the frequency of clinical mastitis cases according to conditions of breeding, they detected it as $4.6 \%$ in outdoor systems, $13 \%$ in indoor systems and $13.1 \%$ in semi-outdoor systems. Rahman et al. [37] detected mastitis cases in managements with block brick ground as $30 \%$ in dry seasons, $58.5 \%$ in wet seasons, and in managements with soil ground as $20 \%$ in dry seasons, $28.6 \%$ in wet seasons. In our study, we found average seropositivity as $65.3 \%$ on concrete grounds and $24.5 \%$ on soil grounds. Mekibib et al. [33] detected positivity as $65 \%$ on muddy soil stable grounds and $52 \%$ on poorly-built stable grounds. In a study [37], the stable ground was stated as a crucial factor in mastitis formation. Especially because soil grounds dried much quicker compared to concrete grounds, fewer mastitis cases existed [38]. This condition is connected with the fact that stable ground creates an important potential source for mastitis factors entering into udder through teats. In wet seasons with intense amounts of water, stable ground creates a potential risk [34]. Muddy and nondrained stable grounds were stated to have prepared a suitable environment for microorganisms to grow as a result of hot weather and increasing level of moisture [39]. Using ground sills for cows and their types are crucial for udder health, milk quality and podiatry. For mastitis, both the type of sill (stalk, sawdust, wood powder, sand, ash, chopped paper, straw and matress) and its volume and replacement frequency is important [40]. California Mastitis Test (CMT) positivity was found as $42.1 \%$ in managements where teat cleaning before and after milking was performed with water and drying was applied, $54.3 \%$ in managements where cleaning was performed only with water and $62.5 \%$ in managements where no cleaning was done [33]. Researchers Bedacha and Menghistu [41] stated the rate of mastitis for those performing disinfection and hand cleaning before milking as $73.8 \%$ while it was $26.2 \%$ for those that did not apply these. Besides, the same researchers [41] found the rate of disinfection and washing udders and teats before milking as $21.4 \%$ while it was $78.6 \%$ for those that did not apply these. Persistence in teat cleaning, suitable stable grounds and their regular cleaning, personal cleaning of milking people, regular teat-dipping applications in milking, fast treatment of clinical cases and diagnosing subclinical mastitis factors were said to cause mastitis prevalence to decrease [37].

During udder inspection evaluations of animals with clinical mastitis, the highest seropositivity was detected in the ones with normal udder, teat and skin appearance. Out of udder and teat skin lesions, the highest seropositivity was detected in crushed ones. During teat palpation evaluations of animals with clinical mastitis, the highest seropositivity was detected in the ones with tissue thickening in teats, and in the ones with elastic teats and lobes. In the milk of these animals, the highest seropositivity was found in coagulated ones. During applications of milking through microorganism entrance via mammary duct from udders and teats and sucking of youngsters, contamination from cow to cow or among udder lobes might take place depending on milking systems [31]. Mekibib et al. [33] reported that they encountered the highest mastitis prevalence $(85.7 \%)$ in udder and teat with injuries. In udder and teat open injuries, clinical mastitis cases $(25.2 \%)$ were reported to be higher than those without injuries (5.4\%) [30]. Besides, they stated that mastitis cases existed in $68.8 \%$ of udder and teat with injuries and in $18.2 \%$ of the ones without injuries [30]. Hussain et al. [42] studied udder and teat lesions of animals detected as mastitis positive for buffaloes. Accordingly, they found teat lesions as $69.57 \%$, skin rashes as $60 \%$, inflammations $65.22 \%$, rope formations as $33.33 \%$, haemorrhage as $60 \%$, necrosis as $50 \%$, udder oedema as $60 \%$ and normal facts as $38.46 \%$. Slettbakk et al. [43] observed the closeness of teat to the bottom, periparturient oedema and teat skewness in animals with clinical mastitis. A relation is considered to exist between mastitis and teat size, the general shape of teats, teat lesions, teat pigmentation and milk viscosity [44] while no consensus was created at the level of books and articles [45].

\section{CONCLUSIONS}

In this study, viruses were thought to take place significantly or viruses were encountered in 
cases of clinical mastitis. They were found especially as single and triple infections. The highest seropositivity was detected against BPIV3 in three-year-old and other age groups. The physical structure of the management, applications of milking-vaccination-treatment and all kinds of cleaning and disinfection were found effective in clinical mastitis development. Besides, udder and teat skin lesions, tissue thickening, elastic udder sinuses and lobes and coagulation of milk was also in the foreground to cause this condition. However, udder shape and teat skin appearance were not considered important in clinical mastitis cases. Mastitis is the most crucial matter in dairy cattle breeding all over the world [46]. To overcome this matter, studies need to be performed as well in detecting factors in terms of viral agents other than the classical approach. By performing experimental and field aimed studies on mastitis cases with viruses and other microorganisms, new data must be obtained. In light of this data, protective strategies and methods must be developed. Herd vaccinations must be applied in order to prevent viral mastitis cases. Individuals must be careful, attentive and sanitated about physical structures of managements, applications on herd health and management and all kinds of applications performed on animals individually.

\section{ETHICAL APPROVAL}

As per international standard or university standard written ethical approval has been collected and preserved by the authors.

\section{ACKNOWLEDGEMENTS}

This study has been supported by Mehmet Akif Ersoy University Coordinatorship of Scientific Research Projects with the project number 0221$\mathrm{YL}-14$. Also, it has been summarized from a part of the project.

\section{COMPETING INTERESTS}

Authors have declared that no competing interests exist.

\section{REFERENCES}

1. Mastitis. In: Veterinary medicine, a text book of the disease of cattle, sheep, goats, pigs and horses. London: Bailliere Tindal; 1994.
2. Miltenburg JD, de Lange D, Crauwels AP, Bongers JH, Tielen MJ, Schukken $\mathrm{YH}$, Elbers AR. Incidence of clinical mastitis in a random sample of dairy herds in the southern Netherlands. Vet Rec. 1996;139: 204-207.

3. Watts JL. Etiological agents of bovine mastitis. Vet Microbiol. 1988;16:41-66.

4. Karaduman M, Gür S. Sağlıklı ve klinik-sub klinik mastitis teşhisi konmuş ineklerde Infectious bovine rhinotracheitis-infectous pustuler vulvovaginitis (IBR) enfeksiyonunun araştırılması, MSc Dissertation-Virology, Afyonkarahisar: Afyon Kocatepe Üniversitesi Sağlık Bilimleri Enstitüsü; 2008.

5. Sharma N. Foot and mouth disease Mastitis cascade in dairy cattle: A field study. Int J Zool Res. 2008;4:64-67.

6. Wellenberg GJ, Van der Poel WHM, Van der Vorst TJK, Van Valkengoed PHR, Schukken YH, Wagenaar F, Van Oirschot JT. Bovine herpesvirus 4 in bovine clinical mastitis. Vet Rec. 2000;147:222-225.

7. Woods GT, Mansfield ME, Krone J. Virological examination of bovine mammary lymph nodes. Can J Comp Med. 1970;34:354-355.

8. Yoshikawa H, Xie B, Oyamada T, Hiraga A, Yoshikawa T. Detection of Bovine Leukemia Viruses (BLV) in mammary tissues of BLV antibody-positive cows affected by subclinical mastitis. J Vet Med Sci. 1997;59:301-302.

9. Leite JA, Drumond BP, Trindade GS, Lobato ZI., da Fonseca FG, dos Santos JR, Madureira MC, Guedes MIMC, Ferreira JMS, Bonjardim CA, Ferreira PCP, Kroon EG. Passatempo virus, a vaccinia virus strain. Brazil. Emerg Infect Dis. 2005;11:1935-1938.

10. Rişvanlı A, Kalkan C. İneklerde meme papillomatozisi ile mastitis arasındaki ilişki. Vet Bil Derg. 2001;17:143-147.

11. Sambyal DS, Verma BB, Baxi KK. A note on an outbreak of cowpox at Taran, Amritsar (Punjab). Indian Vet J. 1983;60: 327-328.

12. Snider TG, Luther DG, Jenny BF, Hoyt PG, Battles JK, Ennis WH, Balady J, BlasMachado U, Lemarchand TX, Gonda MA. Encephalitis, lymphoid tissue depletion and secondary diseases associated with Bovine immunodeficiency virus in a dairy herd. Comp Immunol Microbiol Infect Dis. 1996;19:117-131. 
13. Syed AM, Halmandge SC, Kasaralikar WR, Udupa GK. A successful treatment of bovine ulcerative mammilitis. Vet World. 2009;2:33.

14. Waage $S$. Influence of new infection with bovine virus diarrhoea virus on udder health in Norwegian diary cows. Prev Vet Med. 2000;20:123-135.

15. Wellenberg GJ, van der Poel WHM, Van Oirschot JT. Viral infections and bovine mastitis: A review. Vet Microbiol. 2002a; 88:27-45.

16. Wellenberg GJ, Verstraten ERAM, Jongejan F, Van Oirschot JT. Susceptibility of bovine umbilical cord endothelial cells to bovine herpesviruses and pseudocowpox virus. Vet Res Commun. 2002b;6:407-417.

17. National Milk Council. Dünya ve Türkiye'de Süt Sektör İstatistikleri. Ankara; 2013.

18. Alaçam E, Şahal M, Görgül S, İmren HY, Tuncer ŞD. Sığır Hastalıkları, Ankara: Medisan; 1997.

19. Siegler $\mathrm{HH}$, Marschang $\mathrm{F}$, Morsher $\mathrm{H}$. Beobachtungen uber zusammenhange zwischen Virusinfectionen und boviner Mastitis. Tierarztl Umsch. 1984;39:602604.

20. Burrows R, Mann JA, Greig A, Chapman WG, Goodridge D. The growth and persistence of foot and mouth disease virus in the bovine mammary gland. J Hyg.-Cambridge. 1971;69:307-321.

21. Cai TQ, Weston PG, Lund LA, Brodie B, McKenna DJ, Wagner WC. Association between neutrophil functions and periparturient disorders in cows. Am J Vet Res. 1994;55:934-943.

22. Campo MS. Animal models of papillomavirus pathogenesis. Virus Res. 2002;89:249-261.

23. Herlekar DA, Shashikant CS, Gurjar AA, Jayarao BM. Presence of viral and bacterial organisms in milk and their association with somatic cell counts. J Dairy Sci. 2013;96:6336-6346.

24. Bilge S. Detection of antibodies of IBR-IPV infection in blood and milk by serum neutralization test and virus isolation from milk samples in dairy cows. Ankara Univ Vet Fak Derg. 1998;45:313-321.

25. Ali H, Keefe GP, Cepica A. Bovine Herpesvirus-4, a potential cause of mastitis in Canadian Dairy Cows. Bri J Dairy Sci. 2011;2:31-34.

26. Kawakami Y, Kaji T, Omuro M, Maruyama $\mathrm{Y}$, Hiramune $\mathrm{T}$, Murase $\mathrm{N}$, Matumoto $\mathrm{M}$. Infection of cattle with parainfluenza 3 virus with special reference to udder infection. II. Pathology of the virus to cattle, with particular reference to the mammary gland. Jpn J Microbiol. 1966;10:171-182.

27. Valarcher JF, Hagglund S. Viral respiratory infections in cattle. Proceedings of $\mathrm{XXIV}^{\text {th }}$ World Buiatric Congress. Nice, France: 2006.

28. Bryson DG. Parainfluenza-3 virus in cattle. In: Dinter Z, Morein B, editors. Virus Infections of Ruminants. New York: Elsevier Science Publishers; 1990.

29. Wellenberg GJ, Verstraten ERAM, Belak S, Verschuren SBE, Rijsewijk FAM, Peshev R, Van Oirschot JT. Detection of bovine herpesvirus 4 glycoprotein $\mathrm{B}$ and thymidine kinase DNA by PCR assays in bovine milk. J Virol Methods. 2001;97:101112.

30. Biffa D, Debela E, Beyene F. Prevalence and risk factors of mastitis in lactating dairy cows in Southern Ethiopia. Int J App Res Vet Med. 2005;3:189-198.

31. Girma S, Mammo A, Bogele K, Sori T, Tadesse F, Jibat T. Study on prevalence of bovine mastitis and its major causative agents in West Harerghe zone, Doba district, Ethiopia. JVMAH. 2012;4:116-123.

32. Radostits DM. Herd health, food animal production medicine. Philadelphia: W.B. Saunder; 2003.

33. Mekibib B, Furgasa M, Abunna F, Megersa $B$, Regassa A. Bovine mastitis: Prevalence, risk factors and major pathogens in dairy farm of Holeta town Central Ethiopia. Vet World. 2009;3:397403.

34. Kivaria FM, Noordhuizen JP, Kapaja AM. Risk indicates associated with subclinical mastitis in small holder dairy cows in Tanzania. J Cell Anim Biol. 2004;3:71-77.

35. Çetin M, Alan M. Yüzüncü yıl üniversitesi veteriner fakültesi doğum ve jinekoloji kliniğinde karşılaşılan meme sorunları. Yüzüncü Yıl Üniv Vet Fak Derg. 2008;2:16.

36. Ali T, Rahman A, Qureshi MS, Hussain MT, Khan MS, Uddin S, Iqbal M, Han B. Effect of management practices and animal age on incidence of mastitis in Nili Ravi Buffaloes. Trop Anim Health Prod. 2014;46:1279-1285.

37. Rahman MA, Bhuiyan MMU, Kamal MM, Shamsuddin M. Prevalence and risk factors of mastitis in dairy cows. Bangladesh Veterinarian. 2009;26: 54-60. 
38. Hogan JS, Smith KL, Todhunter DA, Schoenberger PS. Bacterial counts associated with recycled chopped newspaper bedding. J Dairy Sci. 1990;73: 1756-1767.

39. Fox LK, Chester ST, Hallberg JW, Nickerson SC, Pankey JW, Weaver LD. Survey of intramammary infections in dairy heifers at breeding age and first parturition. J Dairy Sci. 1995;78:1619-1628.

40. Baştan A. İneklerde Meme Sağlığı ve Sorunları, Ankara: Kardelen Ofset Matbaacılık Tanıtım Hizmetleri San. Tic. Ltd. Sti.; 2013.

41. Bedacha BD, Menghistu HT. Study on prevalence of mastitis and its associated risk factors in lactating dairy cows in Batu and its environs, Ethiopia. Glob Veterinaria. 2011;7:632-637.

42. Hussain R, Javed MJ, Khan A, Muhammad G. Risks factors associated with subclinical mastitis in water buffaloes in Pakistan. Trop Anim Health Prod. 2013;45:17231729.

43. Slettbakk T, Jorstad A, Farver TB, Holmes JC. Impact of milking characteristics and morphology of udder and teats on clinical mastitis in first and second lactation in Norwegian cattle. Prev Vet Med. 1995;24: 235-244.

44. Hussain R, Khan A, Javed MT, Rizvi F. Possible risk factors associated with mastitis in indigenous cattle in Punjab, Pakistan. Pakistan Vet J. 2012;32:605608.

45. Seykora AJ, McDaniel BT. Udder and teat morphology related to mastitis resistance: A review. J Dairy Sci. 1985;68:2087-2093.

46. IDF World Dairy Summit. IDF 2013 Dünya Süt Zirvesi Raporu. Yokohama; 2013.

(c) 2020 Celik and Kale; This is an Open Access article distributed under the terms of the Creative Commons Attribution License (http://creativecommons.org/licenses/by/4.0), which permits unrestricted use, distribution, and reproduction in any medium, provided the original work is properly cited.

Peer-review history:

The peer review history for this paper can be accessed here: http://www. sdiarticle4.com/review-history/53859 